\title{
Coda
}

Sergei Bogatyrev (University College London)

s.bogatyrev@ucl.ac.uk

\section{Something New about the 1564 Apostol from the Diaghilev- Lifar Collection}

\begin{abstract}
This note reveals new facts about the 1564 Apostol from the DiaghilevLifar Collection by examining some previously unknown notations in the book. In the middle of the seventeenth century a high-ranking hierarch, Metropolitan Kornilii of Kazan and Sviiazhsk donated the book to a church in the Kazan district.
\end{abstract}

Keywords: Ivan Fedorov, Apostol, Metropolitan Kornilii, Kazan, Serge Diaghilev, Serge Lifar, The British Library

Contributions to this volume cover a wide range of topics, from the printing of early Cyrillic editions in the sixteenth century to collecting printed books in the twentieth century. It is appropriate to round-up this volume by making a leap back to Muscovy without loosing sight of arguably the most flamboyant collector of Ivan Fedorov's books, Serge Diaghilev. Ekaterina Rogatchevskaia kindly shared with me an image of a notation in Ivan Fedorov's Apostol of 1564 from the Diaghilev-Lifar collection (fig. 1). The notation is not registered in the bibliographical descriptions of Diaghilev's copy. ${ }^{1}$ Reading this faded inscription proved to be a challenging but rewarding experience. The notation, which dates to $1650 / 51$, sheds a new light on the circulation of the book in Muscovy: ${ }^{2}$

\footnotetext{
${ }^{1}$ British Library, C.104.k.11, fol. 53v. The best description of the Diaghilev copy is Ralph Cleminson, Christine Thomas, Dilyana Radoslavova, Andrej Voznesenskij, Cyrillic Books Printed before 1701 in British and Irish Collections: A Union Catalogue (London: The British Library, 2000), 18. On the history of Diaghilev's Apostol, see Rogatchevskaia's paper in this volume.

${ }^{2}$ In the following floating quotations superscript letters have been inserted in the main line of text and underlined; the ends of lines in the original text are marked with forward slashes.
} 


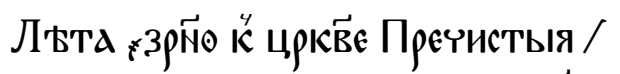

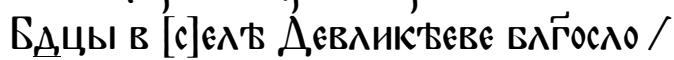

вих преосвеціныИ Митрополитъ /

Корнилин о(-?) сино книгу АПпстлъ /

Бє르 выносеX

In the year of $7159(1650 / 51)$ the eminent Metropolitan Kornilii bestowed this book Acts and Epistles on the church of the Most Holy Mother of God at the hamlet of Devlikeevo [on the condition that the book] would not to be taken out [of the church].

The notation takes us to mid-seventeenth-century Kazan. Kornilii was Metropolitan of Kazan and Sviiazhsk from 1650 through 1656. Prior to this appointment he headed first the Holy Trinity-St. Makarii Zheltovodskii monastery on the Volga river and then the Epiphany monastery in Moscow. After the death of Patriarch Iosif on 15 April 1652 Kornilii acted as locum tenens until the installation of Patriarch Nikon, whom Kornilii ordained on 25 July 1652. Kornilii later attended the church councils which discussed Nikon's reforms and accompanied Tsar Aleksei Mikhailovich during his campaign against Smolensk (1654). Apparently a victim of the plague, the metropolitan died in Kazan on 17 August 1656. He is buried in the Annunciation cathedral in Kazan. ${ }^{3}$ In the middle of seventeenth century the estates of the metropolitan of Kazan included the hamlet of Devlikeevo (Devlekeevo, now Mirnyi in the southern suburbs of Kazan) and satellite villages. ${ }^{4}$ The parish of Devlikeevo was established soon before 1650/51 when the notation in the Diaghilev copy was made. ${ }^{5}$

3 I.A. Ustinova, "Kornilii," in Pravoslavnaia entsiklopediia, 38 (Moscow:

Pravoslavnaia entsiklopediia, 2015), 120-122.

${ }^{4}$ I.P. Ermolaev, D.A. Mustafina, comps., Pistsovaia kniga Kazanskogo uezda 1647-

1656 godov (Moscow: Institut rossiiskoi istorii, Kazanskii gos. universitet, 2001), 37.

${ }^{5}$ In 1790 the first church at Devlikeevo was superseded with a new church dedicated to the Entrance of the Theotokos into the Temple. It is possible that the church mentioned in the notation had the same dedication. See http://sobory.ru/geo/locat/13084\#state-tabs (Narodnyi katalog pravoslavnoi arkhitektury, accessed 9 March 2017); http://www.stmary.ru/history (Istoriia prikhoda Kazanskoi ikony Bozhiei Materi pos. Mirnyi, accessed 9 March 2017). 
The notation is an important source about the circulation of printed books in Kazan. Despite Ivan Fedorov's claim that the annexation of Kazan in 1552 was a major reason for the introduction of printing in Muscovy, we know very little about the distribution of printed editions in Kazan (see A.S. Usachev's paper in this volume). The inscription in the Diaghilev's copy of the Apostol testifies to the engagement of top-level hierarchs with printed books, a practice which goes back to the clerical patronage of early presses in Moscow under Ivan IV (see my paper in the present collection). In 1613 Metropolitan Efrem of Kazan and Sviiazhsk (1606-1613), who presided over the coronation of Mikhail Fedorovich, donated the 1606 Full Gospel printed by Ivan Fedorov's pupil A.M. Radyshevs'kyi to the Annunciation Cathedral in Kazan. ${ }^{6}$ As the inscription in the Diaghilev copy demonstrates, Metropolitan Kornilii followed this lead by donating the 1564 Apostol to the Devlikeevo church. ${ }^{7}$

Printed editions of the Apostol also made their way to other churches in the Volga region. The monasteries of Sviiazhsk had at least two printed copies. The local Trinity monastery received a copy of the 1564 Apostol as a donation in the second half of the sixteenth century (now in the State Historical Museum in Moscow, hereafter GIM). Another unspecified printed edition of the Apostol in folio was registered in the Sviiazhsk Dormition cathedral in 1614. One existing copy of the 1564 edition was in Nizhnii Novgorod in the seventeenth and the first quarter of the eighteenth century (now also in GIM). ${ }^{8}$

\footnotetext{
6 Prior to giving the copy, Efrem commissioned exquisite decorations in it. "Kazanskaia i Tatarstanskaia eparkhiia," in Pravoslavnaia entsiklopediia, 29 (Moscow: Pravoslavnaia entsiklopediia, 2012), 172 (section by E.P. Kliuchevskaia, M.A. Makhan'ko)

${ }^{7}$ For Kornilii's donations of church utensils, see "Kazanskaia i Tatarstanskaia eparkhiia," 177, 178.

${ }^{8}$ E.L. Nemirovskii, Ivan Fedorov i ego epokha: Entsiklopediia (Moscow: Entsiklopediia, 2007), 100-103. The library of the Kazan Federal University has a copy of the 1564 Apostol which originates from Viatka. E.I. Amerkhanova, "Ekzempliar Apostola Ivana Fedorova v fonde Nauchnoi biblioteki im. N.I. Lobachevskogo Kazanskogo federal'nogo universiteta," in D.N. Ramazanova, ed., 450 let Apostolu Ivana Fedorova. Istoriia rannego knigopechataniia v Rossii: Pamiatniki, istochniki, traditsii izucheniia (Moscow: Pashkov dom, 2016), 181183.
} 
The Apostol from the Diaghilev collection was one of the printed copies that circulated in the territory of Kazan and the Volga region. Judging by the poorly preserved inscriptions in the copy and other sources, the history of that book can be reconstructed as follows. After it was printed by Ivan Fedorov and Petr Mstislavets in Moscow in 1564, the copy appeared on the book market in $1605 / 6$, when a certain person, who was probably called Nikifor, son of Ivan, sold the book to the doorkeeper of an unspecified cathedral, Ivan, son of Petr. ${ }^{9}$ In 1650/1 Metropolitan Kornilii donated the book to the church of the Mother of God at Devlikeevo. Some unregistered notations testify to the circulation of the copy among Russian-speaking readers in the late seventeenth or eighteenth centuries. Those include inscriptions in cursive in black ink on paper that was used to restore damaged folios 34v (unclear, a потA-? followed by two or three letters) and 38v (к семy followed by two or three unclear words). There are also two notations executed in amateur uncial in black ink in the right margin of fol. 238:

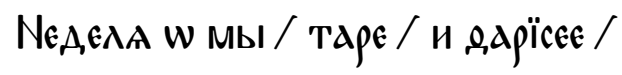

ГАААИ КЕАО / ЖNО / И ПРОЧИТАИ / МЕСПЕШNО

Sunday of the Publican and Pharisee

Note truthfully and read slowly

(written over an erased line of seventeenth-century cursive in brown ink);

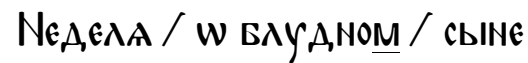

Sunday of the Prodigal Son

The copy from the Diaghilev-Lifar collection thus travelled from Moscow to Kazan, from Kazan to Diaghilev's collection in Paris, from Paris to Sotheby's Monaco auction, and from Monaco to the British Library in London. The

\footnotetext{
${ }^{9}$ For a record of this transaction in the Diaghilev copy, see Cleminson, Cyrillic Books, 18. This catalogue also reproduces fragments of an inscription which the editors interpret as a notation about the book belonging to certain Aleksei (blank leaf between ff. 4 and 5): ГА. record of ownership, but a pupil's inscription, which reads as follows: $\vec{\Gamma}_{A}[\ldots]$ шлєксея (crossed out: вича) [...] вич князя
} 
extensive travels of Diaghilev's Apostol perfectly exemplify the broad connections generated by Ivan Fedorov's press. 


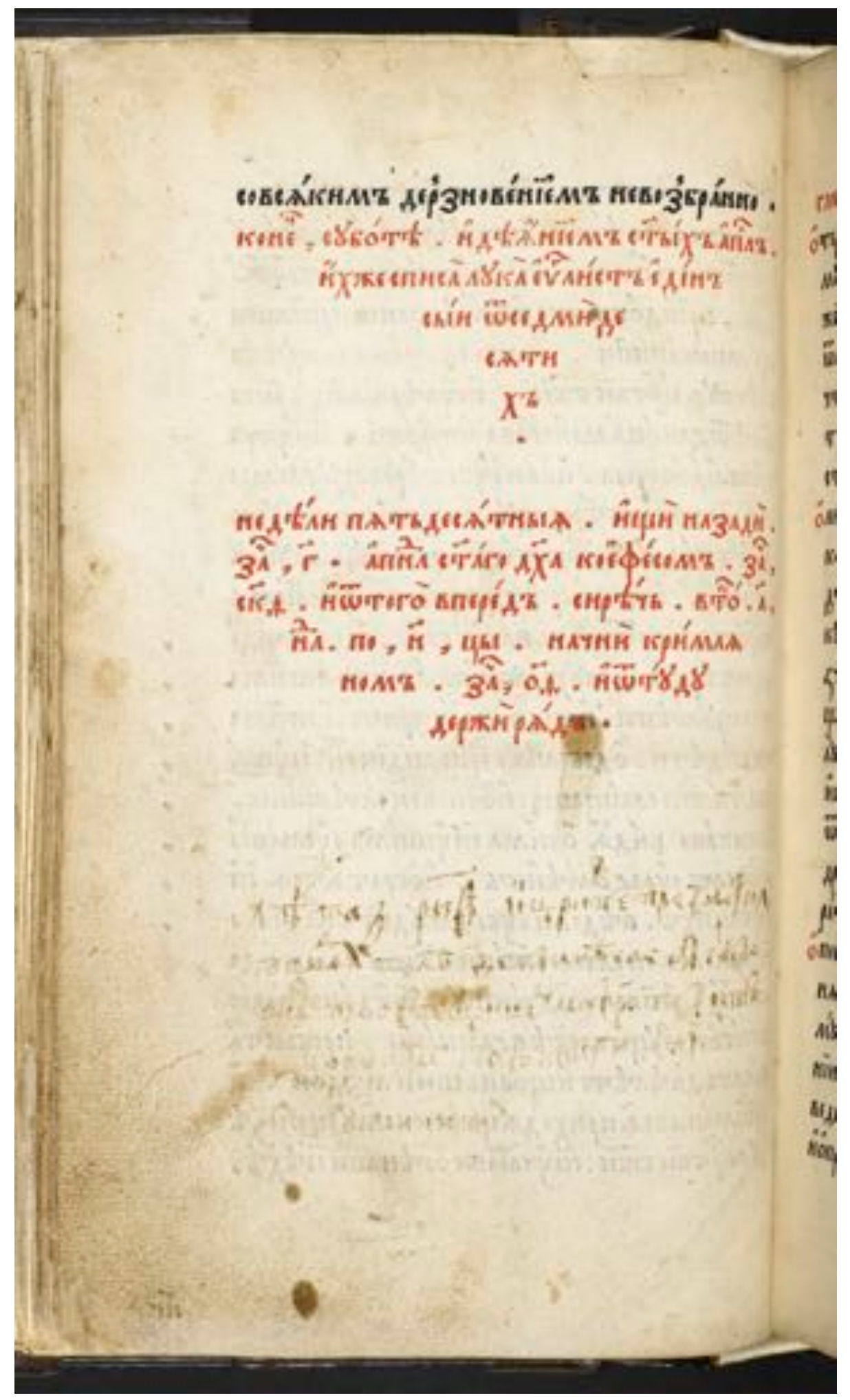

Figure 1: Apostol (Moscow: Ivan Fedorov and Petr Mstislavets, 1564), fol. 53v (notation about the donation of the book by Metropolitan Kornilii to a church in the Kazan region in 1650/51), British Library, C.104.k.11 